$\xi=$

\title{
Safety profile of clarithromycin in broilers after repeated oral administration
}

\author{
Hanady Awadallah ${ }^{1}$, Shaban Awidat ${ }^{1}$, Emad Bennour $^{2}$, Giuma Elhafi ${ }^{3}$, Abubakr El-Mahmoudy $4 *$ \\ ${ }^{1}$ Department of Pharmacology, Toxicology \& Forensic Medicine, Faculty of Veterinary Medicine, University of Tripoli, Tripoli, Libya \\ ${ }^{2}$ Department of Internal Medicine, Faculty of Veterinary Medicine, University of Tripoli, Tripoli, Libya \\ ${ }^{3}$ Department of Clinical Studies, Faculty of Agriculture and Veterinary Medicine, Azzaytuna University, Tarhuna, Libya \\ ${ }^{4}$ Department of Pharmacology, Faculty of Veterinary Medicine, Benha University, 13736 Moshtohor, Egypt \\ *Corresponding author E-mail: a.elmahmoudy@fvtm.bu.edu.eg
}

\begin{abstract}
The effects of repeated oral administration of clarithromycin $(7.5 \mathrm{mg} / \mathrm{Kg}$ B.W., daily for 5 consecutive days) on blood parameters, clinico-chemical parameters and vital organ histology were evaluated in Ross broiler chickens. Twelve clinically healthy birds have been used in a parallel study design, where they have been randomly divided into two groups. The 1st group received a dose of $7.5 \mathrm{mg}$ clarithromycin/Kg as intracrop bolus daily for 5 consecutive days after $6 \mathrm{~h}$ fasting; while the 2 nd group received iso-saline and was kept as control. Blood samples were collected from all birds via the wing and metatarsal vein punctures on the 5th day for clinico-chemical and haematological examinations; and liver, kidneys and heart were dissected out for histopathological examination. Results revealed that repeated administration of clarithromycin caused significant increases in ALP, AST, ALT, CK, urea and creatinine levels, compared to those of control. Metabolic parameters exhibited significant decrease in albumin with consequent decrease in total protein and decreased albumin/globulin ratio. Lipid parameters remained unchanged, compared to control. Leuckogram revealed that total leuckocytic count was decreased as a result of the decreased number of lymphocytes and mid-sized cells. On the other hand, granulocytes number exhibited significant increase (granulocytosis) together with increased number of platelets (thrombocytosis); while erythrogram remained insignificantly affected. Liver and kidney showed inflammatory cellular infiltrations associated with degenerative changes and haemorrhages. Although heart did not show inflammatory cellular infiltrations, yet breakage in some bundles was noted. These data indicate that although clarithromycin did not cause any clinical serious manifestations on the treated birds, yet laboratory analysis revealed some adverse effects on some organs as liver, kidney and heart as well as alterations in some clinic-chemical and hematological parameters; these findings should be taken in consideration during therapy with clarithromycin.
\end{abstract}

Keywords: Broiler Chicken; Clarithromycin; Pharmacovigilance; Safety.

\section{Introduction}

Clarithromycin is a semisynthetic erythromycin-derivative, macrolide antibiotic. It is highly potent against a wide variety of aerobic and anaerobic Gram-positive and Gram-negative organisms, including Mycobacteria, Helicobacter, Mycoplasma, Chlamydia, Legionella, Clostridia and Staphylococci. Clarithromycin exerts its antibacterial action by binding to the $50 \mathrm{~S}$ ribosomal subunits of susceptible bacteria with subsequent suppression of protein synthesis. Clarithromycin differs in chemical structure (Fig. 1) from erythromycin by the methylation of the hydroxyl group at position 6 on the lactone ring (Rodvold 1999).

Clarithromycin has been introduced for human health care especially for $H$. Pylori-induced hyperacidity and gastric ulceration as well as for respiratory disease. Nevertheless, no veterinary products have been yet developed.

Because of its numerous advantages over erythromycin, clarithromycin is an attractive alternative for the treatment of violent bacterial strains in veterinary medicine. However, the lack of pharmacological studies precludes the rational use of this antimicrobial agent in targeted animal species.

The authors have evaluated the pharmacokinetic profile of clarithromycin in broilers (AwadAllah et al. 2016) after single intra- venous bolus and intracrop administrations, where the drug was proved to have a good pharmacokinetic profile. Effectiveness is not the only detrimental factor for drug application; to be safe is also a necessary endpoint. Therefore, in the present study, the authors aimed at evaluation of the drug from the safety point of view in the same species after repeated oral administration.

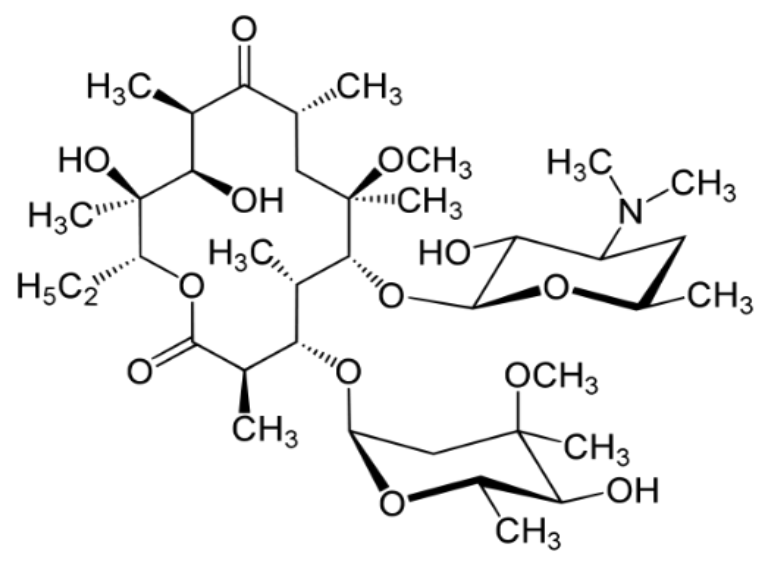

Fig. 1: Structural Formula of Clarithromycin. 


\section{Materials and methods}

\subsection{The drug}

Clarithromycin oral preparation was obtained as $\mathrm{Klacid}^{\circledR}$ powder for oral suspension $\left(250 \mathrm{mg} / 5 \mathrm{ml}\right.$ after reconstitution; Abott ${ }^{\circledR} \mathrm{La}-$ boratories, UK). The drug has the chemical name: 6-Omethylerythromycin; with molecular formula: $\mathrm{C}_{38} \mathrm{H}_{69} \mathrm{NO}_{13}$; and of molecular weight: 47.96. The dose given to each chicken was adjusted to $7.5 \mathrm{mg} / \mathrm{Kg}$ of body weight, repeated daily for $5 \mathrm{con}-$ secutive days, given by a syringe with long plastic cannula to deliver the drug suspension intracrop.

\subsection{Experimental animals}

Twelve healthy, 40 day old, Ross broiler chickens with body weight of about $2 \mathrm{Kg}$ were used. Animals were numbered and accommodated in a suitable pen under hygienic condition with controlled temperature $\left(22 \pm 1^{\circ} \mathrm{C}\right)$, humidity $(60 \pm 10 \%)$ and light (12 h per day) for at least a week before being used. Food and water were available ad libitum; but food was held $6 \mathrm{~h}$ before drug administration. Six birds were assigned to clarithromycin treatment (Group-I); and the other six were used as control (Group-II).

\subsection{Sampling}

Two sites for blood sampling were used: Basilic vein (wing vein) that is located over the medial surface of the proximal ulna, which is much more prone to hematoma; and metatarsal vein that is located above the metatarsus and tibiometatarsal joint (hock) on the median side of the leg, which was preferred. On the $5^{\text {th }}$ day and two hours post last dose, while the drug should has reached its maximal concentration and started distribution phase, three $\mathrm{mL}$ of blood were drawn from each bird in into heparinized tubes properly labelled with group and chicken numbers. Each sample was divided into 2 parts; the first part was kept as a whole blood that was used for haematology; while the second part was centrifuged at $3000 \mathrm{rpm}$ for $10 \mathrm{~min}$ to separate plasma for clinico-chemical investigations. After clean blood collection, the chickens of each group were ethically sacrificed and specimens from liver, kidneys and heart were dissected out into $10 \%$ formol saline to be fixed for twenty-four hours until histopathological examination.

\subsection{Assays}

Safety assessments in broilers after repeated oral administration of $7.5 \mathrm{mg} / \mathrm{Kg}$ clarithromycin, daily for 5 constitutive days, included the following assays:

\subsubsection{Haematological assay}

To assess the blood safety profile of clarithromycin in broilers, the following haematological parameters in control and treated chicken samples were automatically evaluated by auto-haematology analyser (Mindray ${ }^{\circledR}$, Model BC-2800Vet, Shenzhen, China). Erythrocytic parameters included red blood cell (RBC) count, haematocrit value (HCT), mean corpuscular volume (MCV), haemoglobin concentration (HGB), mean corpuscular haemoglobin $(\mathrm{MCH})$ and mean corpuscular haemoglobin concentration (MCHC). Leukocytic parameters included white blood cell (WBC) count, differential leukocyte count (neutrophils, lymphocytes, monocytes, eosinophils, and basophils), platelets' (PLT) concentration, and mean platelet volume (MPV). As previously reported (Ehmeza et al. 2016), usually in blood specimens, the cells are too close to each other to be identified or measured. For this reason, the special provided diluent was used to separate the cells so that they are drawn through the aperture of the auto-analyser one at a time as well as to create a conductive environment for blood analysis. When analysing a whole blood sample, the analyser aspirates $13 \mu \mathrm{L}$ of the sample and dilutes it (1: 308 for WBCs and 1: 44862 for $\mathrm{RBCs}$ ) before proceeding to the actual analysis. After reacting with the diluent and lyse, the cells mainly fall into the following three volume ranges: WBC, 30 350 fL; RBC: $25 \sim 250 \mathrm{fL}$; PLT: $2 \sim 30 \mathrm{fL}$. With the help of the diluent and lysis buffer, the analyser can size the white cells into three sub-populations, lymphocytes, mid-sized cells, and granulocytes. The analyser adopts the Coulter Principle to count RBC, WBC, and PLT cells and to draw their corresponding histograms. The HGB concentration is obtained by the colorimetric method while the MCV and MPV are calculated electronically. The rest of indices are mathematically derived from those according to the following equations:

$$
\begin{aligned}
& \operatorname{HCT}(\%)=\frac{\operatorname{RBC}\left(10^{12} / \mathrm{L}\right) \times \operatorname{MCV}(\mathrm{fL})}{10} \\
& \operatorname{MCH}(p g)=\frac{\operatorname{HGB}(g / d L)}{\operatorname{RBC}\left(10^{12} / \mathrm{L}\right)} \times 10 \\
& \operatorname{MCHC}(\mathrm{g} / \mathrm{dL})=\frac{\mathrm{HGB}(\mathrm{g} / \mathrm{dL})}{\mathrm{HCT}(\%)} \times 100
\end{aligned}
$$

Based on the WBC histogram, this analyser calculates Lymph\%, Mid $\%$ and Gran $\%$ as follows:

$\operatorname{Lymph}(\%)=\frac{\mathrm{PL}}{\mathrm{PL}+\mathrm{PM}+\mathrm{PG}} \times 100$

$\operatorname{Mid}(\%)=\frac{\mathrm{PM}}{\mathrm{PL}+\mathrm{PM}+\mathrm{PG}} \times 100$

$\operatorname{Gran}(\%)=\frac{\mathrm{PG}}{\mathrm{PL}+\mathrm{PM}+\mathrm{PG}} \times 100$

Where, $\mathrm{PL}=$ particles in the lymphocyte region $\left(10^{9} / \mathrm{L}\right) ; \mathrm{PM}=$ particles in the mid-size region $\left(10^{9} / \mathrm{L}\right) ; \mathrm{PG}=$ particles in the granulocyte region $\left(10^{9} / \mathrm{L}\right)$.

$$
\begin{aligned}
& \operatorname{Lymph} \#\left(10^{9} / \mathrm{L}\right)=\frac{\operatorname{Lymph}(\%) \times \operatorname{WBC}\left(10^{9} / \mathrm{L}\right)}{100} \\
& \operatorname{Mid} \#\left(10^{9} / \mathrm{L}\right)=\frac{\operatorname{Mid}(\%) \times \operatorname{WBC}\left(10^{9} / \mathrm{L}\right)}{100} \\
& \operatorname{Gran} \#\left(10^{9} / \mathrm{L}\right)=\frac{\operatorname{Gran}(\%) \times \operatorname{WBC}\left(10^{9} / \mathrm{L}\right)}{100}
\end{aligned}
$$

PLT count $\left(10^{9} / \mathrm{L}\right)$ is measured directly by counting the platelets passing through the aperture; and based on the PLT histogram, the analyser electronically calculates the mean platelet volume (MPV, $\mathrm{fL})$. PCT is derived from the following equation:

$$
\operatorname{PCT}(\%)=\frac{\operatorname{PLT}\left(10^{9} / \mathrm{L}\right) \times \operatorname{MPV}(\mathrm{fL})}{10}
$$

\subsubsection{Clinico-chemical assays}

Hepatotoxicity, nephrotoxicity, cardiotoxicity and/or metabotoxicity were indicated by their biomarker level determination spectrophotometrically (Jenway ${ }^{\circledR}$, Model 6500, Germany) using diagnostic kits purchased from Analyticon ${ }^{\circledR}$ Biotechnologies AG (Lichtenfels, Germany). The parameters were alkaline phosphatase (Bessey et al. 1946), aspartate aminotransferase (Bergmeyer et al. 1986), alanine aminotransferase (Bergmeyer et al. 1986), total protein (Tietz 1995), creatine kinase (Black et al. 1986), albumin (Marshall 1988), urea (Krieg et al. 1986), creatinine (Bartels et al. 1972), glucose (Schmidt 1961), and total cholesterol (Allain et al. 1974). Plasma triacylglycerols level was estimated using a diagnostic kit purchased from Biolabo ${ }^{\circledR}$ SA (Maizy, France) according to Fossati and Prencipe (1982). Globulin level was calculated by subtracting the value of albumin from the value of total protein according to Doumas and Biggs (1972).

\subsubsection{Histopathological assay}

The liver, heart and the two kidneys were taken from sacrificed birds in both groups and preserved in neutral formalin solution $10 \%$ 
and subjected for histopathological examination according to Bancroft and Gamble (2008). After 24 hours of fixation, samples were washed by running water over night. The washed samples were dehydrated by using graded increased concentrations of ethyl alcohol starting with $70 \%$ and ending with absolute alcohol. The dehydrated samples were immersed in xylol for 3 hours till clearance and then embedded in melted paraffin wax that was left to solidify after tissue immersion. Thin sections $(4-6 \mu \mathrm{m})$ were prepared from the solidified paraffin blocks by a rotative microtome (Leica ${ }^{\circledR}$, Germany).

For staining, paraffin was removed from the sections by two changes of absolute alcohol (five minutes in each) which was removed by washing with tap water. Sections were stained with Harris haematoxylin and eosin for 10 minutes, and then washed with running water for 15 minutes. Stained samples were then dehydrated by different concentrations of alcohol, and then immersed in xylol for clearance and covered by DBX. The obtained slides were subjected for routine microscopical examination to evaluate clarithromycin-induced alterations, if any.

\subsection{Statistical analysis}

Data were expressed as mean \pm standard error of the mean of 6 observations (n). Differences between control and treated groups were tested for significance using Student's t-test. P-values of 0.05 or less were considered significant. All statistical analytical procedures were done using SPSS software v.20 (Chicago, Illinois, USA).

\section{Results}

Table (1) shows the effects of clarithromycin repeated administration on organ (liver, kidney and heart) function profiles of broiler chickens. Clarithromycin caused significant increases in ALP, AST, ALT, CK, urea and creatinine levels, compared to those of control.

Table (2) shows the effects of clarithromycin repeated administration on selected metabolic parameters in broiler chickens. Clarithromycin caused significant decrease in albumin with consequent decrease in total protein and decreased albumin/globulin ratio. Glucose although decreased, yet insignificant. Lipid parameters remained unchanged, compared to control.

Tables (3) and (4) show the effects of clarithromycin treatment for 5 consecutive days) on leuckogram and erythrogram, respectively in broiler chickens. Leuckocytic parameters showed some significant changes when compared to those of control. Total leuckocytic count was decreased as a result of the decreased number of lymphocytes and mid-sized cells. On the other hand, granulocytes number exhibited significant increase (granulocytosis) together with increased number of platelets (thrombocytosis).

Table 1: Effect of Repeated Oral Administration of Clarithromycin (7.5 $\mathrm{mg} / \mathrm{Kg}$; Intracrop; for 5 Consecutive Days) on Organ Function Profile of Broiler Chickens (Mean \pm SEM; $n=6$ )

\begin{tabular}{lllllll}
\hline & $\begin{array}{l}\text { ALP } \\
\text { (IU/L) }\end{array}$ & $\begin{array}{l}\text { AST } \\
\text { (IU/L) }\end{array}$ & $\begin{array}{l}\text { ALT } \\
\text { (IU/L) }\end{array}$ & $\begin{array}{l}\text { CK } \\
(\mathrm{IU} / \mathrm{L})\end{array}$ & $\begin{array}{l}\text { Urea } \\
(\mathrm{mg} / \mathrm{dL})\end{array}$ & $\begin{array}{l}\text { Cr. } \\
(\mathrm{mg} / \mathrm{dL})\end{array}$ \\
\hline \multirow{3}{*}{ Control } & 171.77 & 132.39 & 61.14 & 106.57 & 16.39 & 0.49 \\
& \pm & \pm & \pm & \pm & \pm & \pm \\
& 36.08 & 11.02 & 6.65 & 9.18 & 2.24 & 0.05 \\
$\begin{array}{l}\text { Clar- } \\
\text { ithromy- } \\
\text { cin }\end{array}$ & $\begin{array}{l} \pm \\
\text { cin }\end{array}$ & $191.06^{*}$ & $97.66^{*}$ & $164.93^{*}$ & $37.19^{*}$ & $0.66^{*}$ \\
\hline
\end{tabular}

*Significantly different from corresponding Control (P < 0.05); Cr. (Creatinine).

Figures (2 7) are showing the histological structures of liver, kidney and heart of birds with or without clarithromycin treatment ( $7.5 \mathrm{mg} / \mathrm{Kg}$; intracrop; for 5 consecutive days). Liver and kidney showed inflammatory cellular infiltrations associated with degenerative changes and haemorrhages. Although heart did not show inflammatory cell infiltrations, yet breakage in some bundles was noted.
Table 2: Effect of Repeated Oral Administration of Clarithromycin (7.5 $\mathrm{mg} / \mathrm{Kg}$; Intracrop; for 5 Consecutive Days) on Some Metabolic Biomarkers in Broiler Chickens (Mean \pm SEM; $\mathrm{N}=6$ )

\begin{tabular}{lllllll}
\hline & TP & ALB & GLB & GLU & CHOL & TAG \\
$(\mathrm{g} / \mathrm{dL})$ & $(\mathrm{g} / \mathrm{dL})$ & $(\mathrm{g} / \mathrm{dL})$ & $(\mathrm{mg} / \mathrm{dL})$ & $\begin{array}{l}\mathrm{mg} / \mathrm{dL}) \\
(\mathrm{mg} / \mathrm{dL})\end{array}$ \\
\hline & 5.54 & 2.15 & 3.29 & 277.36 & 129.98 & 91.83 \\
Control & \pm & \pm & \pm & \pm & \pm & \pm \\
& 0.166 & 0.06 & 0.15 & 15.09 & 7.87 & 4.99 \\
Clar- & $5.19^{*}$ & $1.79^{*}$ & 3.21 & 261.91 & 120.20 & 95.12 \\
ithromy- & \pm & \pm & \pm & \pm & \pm & \pm \\
cin & 0.25 & 0.08 & 0.23 & 12.07 & 12.05 & 11.50 \\
\hline
\end{tabular}

*Significantly different from corresponding Control $(\mathrm{P}<0.05)$

Table 3: Effect of Repeated Oral Administration of Clarithromycin (7.5 $\mathrm{mg} / \mathrm{Kg}$; Intracrop; for 5 Consecutive Days) On Leuckogram in Broiler Chickens (Mean $\pm \mathrm{SE} ; \mathrm{n}=6$ )

\begin{tabular}{|c|c|c|c|c|c|c|c|}
\hline & $\begin{array}{l}\text { WBC } \\
\left(10^{9} / \mathrm{L}\right)\end{array}$ & $\begin{array}{l}\text { Lymph. } \\
\left(10^{9} / \mathrm{L}\right)\end{array}$ & $\begin{array}{l}\text { Mid. } \\
\left(10^{9} / \mathrm{L}\right)\end{array}$ & $\begin{array}{l}\text { Gran. } \\
\left(10^{9} / \mathrm{L}\right)\end{array}$ & $\begin{array}{l}\text { PLT } \\
\left(10^{9} / \mathrm{L}\right)\end{array}$ & $\begin{array}{l}\text { PCT } \\
(\%)\end{array}$ & $\begin{array}{l}\begin{array}{l}\text { MPV } \\
\text { (fL) }\end{array} \\
\end{array}$ \\
\hline & 21.912 & 8.690 & 3.70 & 8.817 & 63.20 & 0.04 & 6.13 \\
\hline Control & $\begin{array}{l} \pm \\
0.310\end{array}$ & $\begin{array}{l} \pm \\
0.384\end{array}$ & $\begin{array}{l} \pm \\
0.35\end{array}$ & & & $\begin{array}{l} \pm \\
0.009\end{array}$ & $\begin{array}{l} \pm \\
0.13\end{array}$ \\
\hline $\begin{array}{l}\text { Clarith- } \\
\text { romycir }\end{array}$ & $\begin{array}{l}20.147 * \\
\pm \\
0.390\end{array}$ & $\begin{array}{l}7.438 \\
\pm \\
0.547\end{array}$ & $\begin{array}{l}2.522 \\
\pm \\
0.137\end{array}$ & $\begin{array}{l}10.187 * \\
\pm \\
0.536\end{array}$ & $\begin{array}{l}117.2^{*} \\
\pm \\
11.8\end{array}$ & $\begin{array}{l}0.07 \\
\pm \\
0.007\end{array}$ & $\begin{array}{l}5.75 \\
\pm \\
0.06\end{array}$ \\
\hline
\end{tabular}

*Significantly different from corresponding Control $(\mathrm{P}<0.05)$

Table 4: Effect of Repeated Oral Administration of Clarithromycin (7.5 $\mathrm{mg} / \mathrm{Kg}$; Intracrop; for 5 Consecutive Days) on Erythrogram in Broiler Chickens (Mean \pm SE; $n=6$ ).

\begin{tabular}{lllllll}
\hline & $\begin{array}{l}\text { RBC } \\
\left(10^{12} / \mathrm{L}\right)\end{array}$ & $\begin{array}{l}\mathrm{HGB} \\
(\mathrm{g} / \mathrm{dL})\end{array}$ & $\begin{array}{l}\mathrm{HCT} \\
(\%)\end{array}$ & $\begin{array}{l}\mathrm{MCV} \\
(\mathrm{fL})\end{array}$ & $\begin{array}{l}\mathrm{MCH} \\
(\mathrm{pg})\end{array}$ & $\begin{array}{l}\text { MCHC } \\
(\mathrm{g} / \mathrm{dL})\end{array}$ \\
\hline \multirow{3}{*}{ Control } & 2.74 & 15.58 & 34.52 & 119.13 & 53.85 & 45.18 \\
& \pm & \pm & \pm & \pm & \pm & \pm \\
& 0.15 & 0.52 & 1.29 & 1.00 & 1.89 & 1.24 \\
Clarithro- & 2.53 & 14.18 & 31.65 & 116.15 & 54.23 & 46.40 \\
mycin & \pm & \pm & \pm & \pm & \pm & \pm \\
& 0.10 & 0.43 & 1.17 & 0.60 & 0.99 & 0.71 \\
\hline
\end{tabular}

*Significantly different from corresponding Control $(\mathrm{P}<0.05)$

\section{Discussion}

Safety is a deterministic demand in drug approval for therapy in man and animals. Many drugs, though effective, have not been approved or banned because of their unsatisfactory safety profile. Estimation of plasma clinico-chemical biomarkers, blood parameters and indices, as well as histopathological alterations may give a major picture about assessment of a drug safety. Liver and kidney, in particular, are target organs as they are the sites of drug metabolism and elimination.

The authors have reported earlier the good pharmacokinetic profile of clarithromycin in broiler chickens after oral and intravenous administrations (AwadAllah et al. 2016); here, the safety profile of the drug was evaluated in the same species at the same dose regimen.

Clarithromycin is one of macrolide antimicrobial agents that are chemically comprised of a lactone ring with $13,14,15$ or 16 carbons attached to 2 sugar moieties.

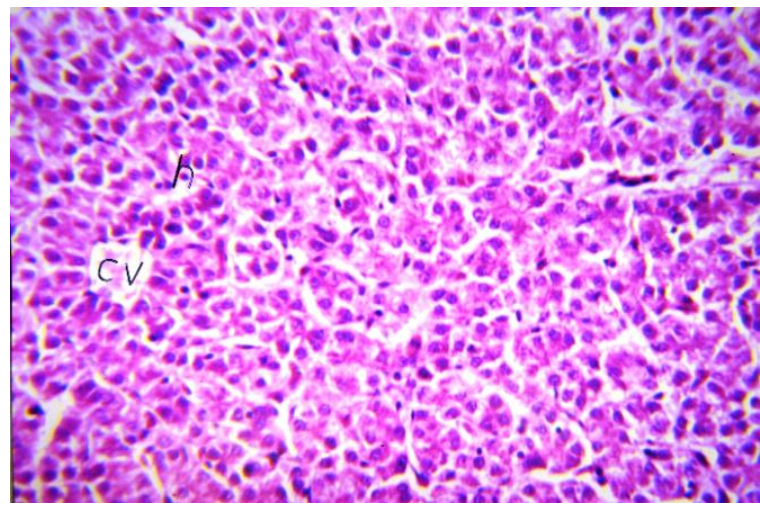

Fig. 2: Liver of A Control Bird Showing Normal Histological Structure of the Central Vein (CV) Surrounding Hepatocytes (H); (H\&E, X40). 
Clarithromycin as all macrolides can inhibit protein synthesis by reversibly binding to $50 \mathrm{~S}$ subunits of the ribosome. By this mechanism of action, this group of antibacterials are generally bacteriostatic agents.

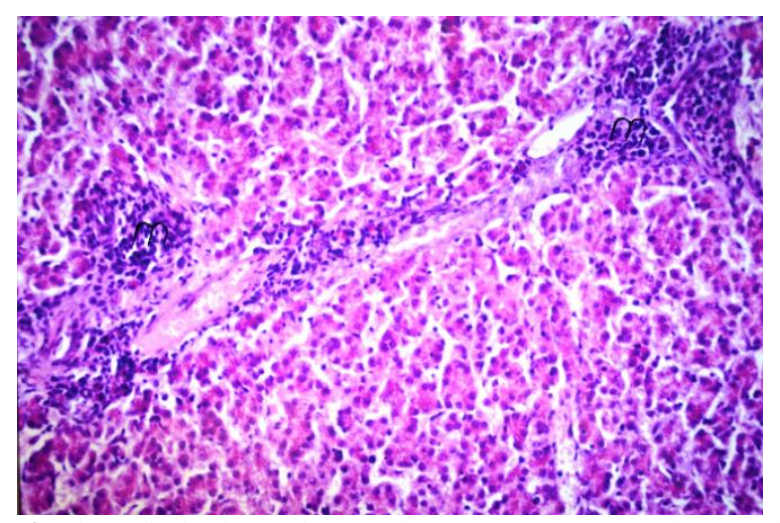

Fig. 3: Liver of Bird in Clarithromycin-Treated Group Showing Massive Inflammatory Cell Infiltration (M) in Portal Area (H\&D, X40).

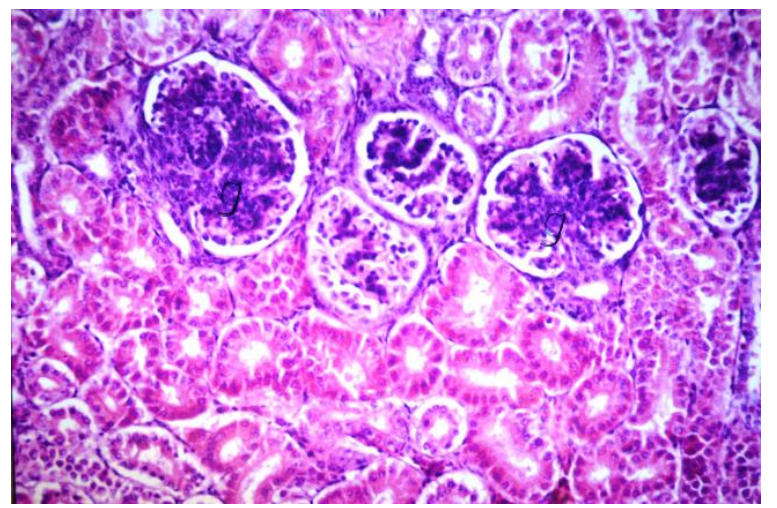

Fig. 4: Kidney of Bird in Control Group Showing Normal Histological Structure of Glomeruli (G) and Tubules (T); (H\&D X40).

Their spectrum of activity includes mostly Gram-positive microorganisms, most Mycoplasma spp., some Chalmydiae as well as some Gram-negative pathogens such as Haemophilus influenzae, Campylobacter jejuni, Bordetella spp., Helicobacter pylori and Mannheimia haemolytica (Alvarez-Elcoro and Enzler 1999). Accordingly, this class of antimicrobials has been effectively applied in the treatment of respiratory tract, skin, and soft tissue infections, $H$. pylori-induced acidity as well as venereal disease in man. In veterinary medicine, some macrolides as erythromycin, tilmicosin, tulathromycin are also approved for the treatment of bronchopneumonia in cattle, Rhodococcus equi infections in foals and chronic respiratory disease (CRD) in poultry.

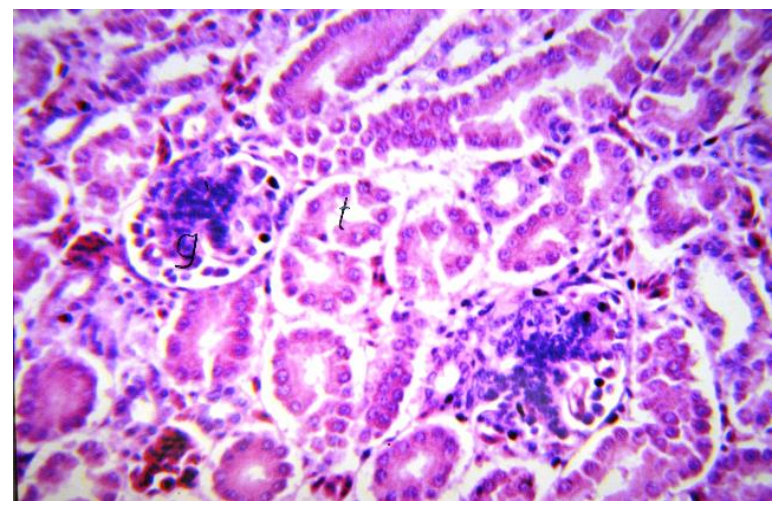

Fig. 5: Kidney of Bird in Clarithromycin-Treated Group Showing Proliferation in Lining Endothelial Cells of the Glomerular Tuft (G) with Hypertrophy, Inflammatory Cell Infiltration and Haemorrhage (H\&D, X40).

Clarithromycin is a semi-synthetic macrolide, derived from erythromycin. It has been approved for the use in man for the treatment of pharyngitis/tonsillitis due to Streptococcus pyogenes; acute maxillary sinusitis due to Haemophilus influenzae, Moraxella catarrhalis, or Streptococcus pneumoniae; community acquired pneumonia or bronchitis due to some microbes as Haemophilus influenzae, Mycoplasma pneumoniae, Streptococcus pneumoniae,

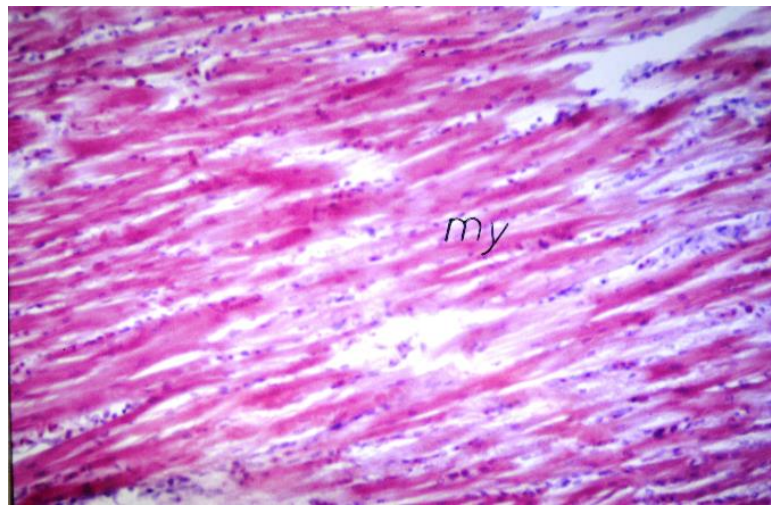

Fig. 6: Heart of Bird in Control Group Showing Normal Histological Structure of the Myocardial Bundles (My) (H\&E X40).

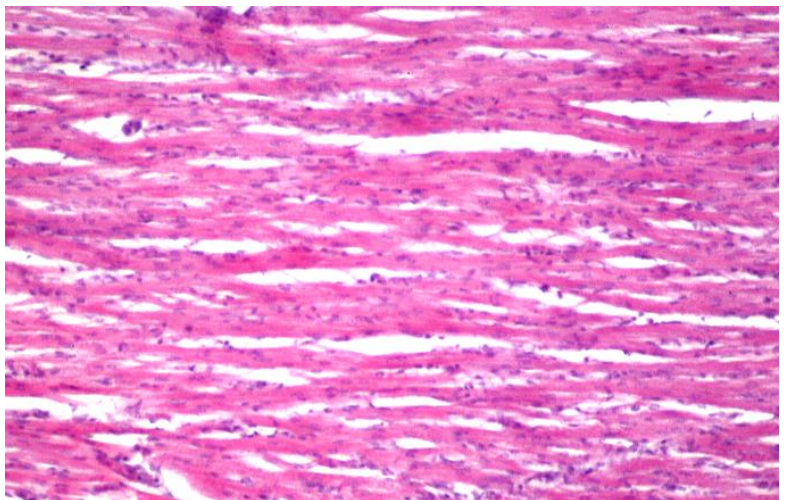

Fig. 7: Heart of Bird in Clarithromycin-Treated Group Showing Breakage in Some Myocardial Bundles (H\&D, X40).

Moraxella catarrhalis, or Chlamydia pneumoniae; uncomplicated skin infection due to Staphylococcus aureus, or Streptococcus pyogenes; disseminated mycobacterial infections due to Mycobacterium avium; and as a combined therapy with amoxicillin and a proton pump inhibitor for the treatment of gastric and duodenal ulceration caused by Helicobacter pylori. Only a few studies have been performed using clarithromycin in animals, particularly poultry. Because of current unavailability of veterinary formulations of this macrolide, this study, therefore, has been performed with the only commercialized formulation of clarithromycin for human use.

The hepatic biomarkers in clarithromycin-treated group in the present study showed significant difference from those of control group. ALP, ALT and AST activity values at the tested dose of clarithromycin were significantly increased compared to those of the controls, especially that of ALP. ALT is a cytoplasmic enzyme and its increased level in plasma is an indication of mild injuries caused by the drug to the liver. While AST is a mitochondrial enzyme whose increased activity in plasma reflects severe hepatic tissue injury (Crook 2006). Although ALP is formed mostly in the liver, yet, it is nonspecific to hepatic injury as it is formed by other tissues as bone, kidney, skeletal muscle and placenta. However, the degenerative changes in the liver tissue showed in figure (3) may give a support to the hypothesis of hepatic injury caused by clarithromycin administration. Oral administration may be stressful on the liver more than injection because of the first pass effect. It is also worthy to note that ALP concentration in juvenile birds is significantly higher than that of adult birds as it is induced by increased cellular activity and synthesis rather than cell damage. In contrast to mammals, ALP of birds is also found at higher concentrations in duodenum and kidney (Clubb et al. 1990). Elevated liver function biomarkers are also reported after clarithromycin in rats (Olayinka and Ore 2012) and man (Fraschini et al. 1993). 
Clarithromycin at a dose of $7.5 \mathrm{mg} / \mathrm{Kg} \mathrm{B.W}$ resulted in increased plasma levels of urea and creatinine. Urea is formed in the liver and represents the principle end product of protein catabolism. It is excreted almost entirely by the kidneys and about 25 to $40 \%$ of the filtered urea is reabsorbed. Glomerular filtration rate is the main factor affecting the excretion of urea, when it increases, plasma urea will decrease and vice versa. Urea clearance means the ability of the kidney to excrete certain amount of urea in the urine in a given time. This gives a good indication about kidney function and glomerular filtration rate. In the present study, clarithromycin-induced increased urea concentration in plasma may indicate that clarithromycin impaired the ability of the kidneys to excrete urea in urine. This might be attributed to pathological alterations of renal tubules and/or decreased glomerular filtration rate due to proliferation of the glomerular tuft which nearly filled the Bowman's space (Figure 5). The obtained result is consistent with those reported by (Olayinka and Ore 2012) in rats and (Jacks et al. 2002) in man.

Creatinine is a non-protein nitrogenous substance formed during muscle metabolism of creatine phosphate. The amount of creatinine produced by normal body is constant and it is excreted by glomerular filtration and not reabsorbed, so its excretion is dependent on the rate of glomerular filtration. Creatinine clearance means the ability of the kidney to excrete certain amount of creatinine in the urine in a given time. This gives a good indication about kidney function and glomerular filtration rate. The increase in plasma creatinine after intra-crop administration of clarithromycin recorded in the present study may indicate that clarithromycin impairs the ability of the kidneys to excrete creatinine in urine. This might be attributed to the same causes reported above for urea. This result is consistent with those reported by (Olayinka and Ore 2012) and (Fraschini et al. 1993).

Creatine kinase (CK) is a dimeric enzyme occurring in four different forms: a mitochondrial isoenzyme and the cytosolic isoenzymes CK-MM (muscle type), CK-BB (brain type) and CK-MB (myocardial type). The determination of CK and CK-isoenzyme activities is utilized in the diagnosis and monitoring of myocardial infarction and myopathies. Following injury to the myocardium, $\mathrm{CK}$ is released from the damaged myocardial cells. In early cases, a rise in the CK activity can be found just 4 hours after an injury, the CK-activities reaches a maximum after 12-24 hours and then falls back to the normal range after 3-4 days. Elevated levels of CK reported in this study may indicate a possible mild damaging effect of clarithromycin on the myocardial cells of treated broilers. The result is consistent with the histopathological finding (Figure 7) as well as those reported by (Ohtani et al. 2000) in rat.

Glucose is the primary energy source for the animal body. It is derived from the breakdown of carbohydrates in diet and in body stores as well as by endogenous synthesis from protein or the glycerol moiety of triglycerides. Glucose level in blood is maintained within a fairly narrow range by regulatory hormones such as insulin, glucagon or epinephrine. Glucose is excreted in urine in minute undetectable amount which in turn reabsorbed by renal tubules whatever it is within the normal range. Clarithromycin administration at a dose of $7.5 \mathrm{mg} / \mathrm{Kg}$ bw, orally insignificantly decreased plasma glucose in the present study. This may be attributed to the decreased rate of glycogenolysis or gluconeogenesis due to occurred liver damage mentioned earlier and/or to irritation by clarithromycin of pancreatic cells with enhancement of insulin secretion.

The present study showed that clarithromycin at the given dose to broilers caused significant decline total protein level due to decreased rate of albumin synthesis and decreased albumin/globulin ratio. Decrease of albumin synthesis may follow hepatic dysfunction caused by clarithromycin. Albumin, therefore, is considered as a negative acute phase protein that is decreased in inflammation especially that of the liver where albumin is synthesized. This result may be consistent with the finding that some macrolide members may cause hypoprteinaemia such as tilmicosin (Xie et al. 2011).
Lipid parameters did not show significant changes after clarithromycin treatment in broiler chickens.

Blood picture is an important indicator for safety/toxicity studies in pharmacology especially for those drugs that may accumulate in blood cells like clarithromycin. Repeated intra-crop administration of clarithromycin did not cause significant changes in almost all erythrocytic parameters. Just haemoglobin showed slight, yet, significant decrease compared to that of control. Leuckocytic parameters, in contrast, showed significant leucopenia with granulocytosis. Leucopenia caused by decreased number of agronulocytes (lymphocytes and mid-sized cells) while granulocytosis may be caused by eosinophilia. Eosinophils is a cellular marker for inflammatory conditions that, here, may be caused by the administered clarithromycin in some body organs including liver, kidney as well as intestines. This data may be consisted with clinical pharmacokinetic report after use of clarithromycin in man published by (Rodvold 1999).

\section{Conclusion}

Although clarithromycin did not cause any clinical serious manifestations on the treated birds, yet laboratory analysis revealed some adverse effects on some organs as liver, kidney and heart as well as alterations in some clinico-chemical and hematological parameters. Even though, the study recommends the use of clarithromycin in broilers as the recorded side effects may be a common feature of all drugs and disappear after completing the course of drug therapy.

\section{Acknowledgement}

The authors would like to thank Prof. Dr. Sabry El-Khodery, Department of Animal Medicine, Mansoura University, Egypt, for kind help and guidance in blood analysis.

Thanks are also attributed to Prof. Dr. Adel Bakeer, Department of Pathology, Cairo University, Egypt, for performing histopathological examination.

\section{References}

[1] Allain CC, Poon LS, Chan CS, Richmond W \& Fu PC (1974), Enzymatic determination of total serum cholesterol. Clinical Chemis try 20, 470-475.

[2] Alvarez-Elcoro S \& Enzler MJ (1999), the macrolides: erythromycin, clarithromycin, and azithromycin. In: Mayo Clinic Proceedings Elsevier. P 613-634. http://dx.doi.org/10.4065/74.6.613.

[3] AwadAllah H, Awidat S \& El-Mahmoudy A (2016), Pharmacokinetics of clarithromycin after single intravenous and intracrop bolus administrations to broiler chickens. International Journal of Phar$\begin{array}{llll}\text { macology and } & \text { Toxicology } & \text { 12-18. }\end{array}$ http://dx.doi.org/10.14419/ijpt.v4i1.5846.

[4] Bancroft JD \& Gamble M (2008), Theory and practice of histological techniques: Elsevier Health Sciences.

[5] Bartels H, Böhmer M \& Heierli C (1972), Serum creatinine determination without protein precipitation. Clinica Chimica Acta 37, 193. http://dx.doi.org/10.1016/0009-8981(72)90432-9.

[6] Bergmeyer H, Herder M \& Ref R (1986), International Federation of Clinical Chemistry (IFCC). J Clin Chem Clin Biochem 24, 497510 .

[7] Bessey O, Oliver H \& Jane M (1946), A method for the rapid determination of alkaline phosphatase with five cubic millimeters of serum. Journal of Biological Chemistry 164, 321-329.

[8] Black HR, Quallich H \& Gareleck CB (1986), racial differences in serum creatine kinase levels. The American Journal of Medicine 81, 479-487. http://dx.doi.org/10.1016/0002-9343(86)90303-7.

[9] Clubb SL, Schubot RM, Joyner K, Zinkl JG, Wolf S, Escobar J, Clubb KJ \& Kabbur MB (1990), Hematologic and serum biochemical reference intervals in juvenile eclectus parrots (Eclectus roratus). Journal of the Association of Avian Veterinarians 218-225. http://dx.doi.org/10.2307/27670971.

[10] Crook M (2006), Clinical chemistry \& metabolic medicine: Hodder Arnold London. 
[11] Doumas BT \& Biggs HG (1972), Determination of serum globulins. In: Cooper GR, editor. Standard Methods of Clinical Chemistry. New York, NY: Academic Press. p 175.

[12] Ehmeza N, Elmajdoub A, Abusnina A, Bennour E, Elhafi G \& ElMahmoudy A (2016), Comparative safety profiles of two enrofloxacin generics after repeated intracrop administration to broilers. International Journal of Biological Research 4, 170-176.

[13] Fossati P \& Prencipe L (1982), Serum triglycerides determined colorimetrically with an enzyme that produces hydrogen peroxide. Clinical Chemistry 28, 2077-2080.

[14] Fraschini F, Scaglione F \& Demartini G (1993), Clarithromycin clinical pharmacokinetics. Clinical Pharmacokinetics 25, 189-204. http://dx.doi.org/10.2165/00003088-199325030-00003.

[15] Jacks S, Giguere S, Gronwall R, brown M \& Merritt K (2002), Disposition of oral clarithromycin in foals. Journal of Veterinary Pharmacology and Therapeutics 25, 359-362. http://dx.doi.org/10.1046/j.1365-2885.2002.00420.x.

[16] Krieg M, Gunsser K, Steinhagen-Thiessen E \& Becker H (1986), Comparative quantitative clinico-chemical analysis of the characteristics of 24-hour urine and morning urine. Journal of clinical chemistry and clinical biochemistry Zeitschrift fur klinische Chemie und klinische Biochemie 24, 863-869.

[17] Marshall W (1988), Plasma proteins. Illustrated textbook of clinical chemistry. In: londres: gower Medical Publishing.

[18] Ohtani H, Taninaka C, Hanada E, Kotaki H, Sato H, Sawada Y \& Iga T (2000), Comparative pharmacodynamic analysis of QT interval prolongation induced by the macrolides clarithromycin, roxithromycin, and azithromycin in rats. Antimicrobial Agents and Chemotherapy 44, 2630-2637. http://dx.doi.org/10.1128/AAC.44.10.2630-2637.2000.

[19] Olayinka E \& Ore A (2012), Administration of Clarithromycin (Claricin $\left.{ }^{\circledR}\right)$ Induces Changes in Antioxidant Status and Biochemical Indices in Rats. Research Journal of Pharmacology 6, 52-61.

[20] Rodvold KA (1999), Clinical pharmacokinetics of clarithromycin. $\begin{array}{lll}\text { Clinical } & \text { Pharmacokinetics } & 37,\end{array}$ http://dx.doi.org/10.2165/00003088-199937050-00003.

[21] Schmidt F (1961), Enzymatic determination of glucose and fructose simultaneously. Klinische Wochenschrift 39, 1244-1247. http://dx.doi.org/10.1007/BF01506150.

[22] Tietz NW (1995), Clinical guide to laboratory tests WB Saunders Philadelphia, PA.

[23] Xie S, Wang F, Wang Y, Zhu L, Dong Z, Wang X, Li X \& Zhou W (2011), acute toxicity study of tilmicosin-loaded hydrogenated castor oil-solid lipid nanoparticles. Particle and fibre toxicology 8, 1 10. http://dx.doi.org/10.1186/1743-8977-8-33. 